"THE CONDUCT OF SANITARY INSPECTORS IMPUGNED."

\section{To the Editors of THE LANOHT.}

SIRS,-We, the undersigned sanitary inspectors for the Vestry of Chelsea, having read the article in the Daily Mail of Dec. 9th on the "alleged blackmail by sanitary inspectors," subsequently copied by your valuable journal, beg to ask for the most searching inquiry into the whole statement.

The writer of the article says there is perhaps one honest inspector in 50. As there are about 200 inspectors in London there is ample margin given to substantiate the assertion of dishonesty, and if it can be proved that the statement is true even to the extent of one "dishonest inspector in 50 we think you will be doing a public daty in exposing this alleged dishonesty. We would urge you not to let this matter rest now that you have helped make the statement public until a thorough investigation has taken place, and either the 196 alleged dishonest inspectors in London have been removed from office and dealt with under the Bribes Act or the statement withdrawn.

It cannot be denied that the lives of thousands depend on receiving a pure milk-supply, and as all milk vendors in London are registered there should be no difficulty in substantiating the statements that cheques and post-cards pass at least twice yearly between milk retailer and inspectors. We have counted the number of milk retailers in Chelsea and find they amount to about 150 , so that if any post-cards and cheques do exist there should be no difficulty in finding a few here. We shall be very pleased to assist you in any steps you may think fit to take to arrive at the true state of affairs. We remain, Sirs, yours faithfully,

ALEXr. Grant (Chief).

JAMES W. KING.

War. THORPE.

Ge0. R. METZliER.

Public Health Department, Town Hall, Chelsea, Dec. 19th, 1899.

\section{THE MEDICAL DEFENCE UNION AND THE LONDON AND COUNTIES MEDICAL PROTECTION SOCIETY.}

\section{To the Elitors of THE LANOET.}

SIRs, - The publication in your columns by the council of the Medical Protection Society of the fact that recent attempts to effect amalgamation of the two defence societies have again failed will cause some disappointment to those members of both societies who think amalgamation desirable and who perhaps do not realise the difficulties which exist. There is no need to attribute this failure to ill-will on either side; the failure is due to the fact that no one has yet been able to devise a scheme which will satisfy the legitimate requirements of those who are responsible for safeguarding the interests of each society; and neither society, it appears to me, should feel offended if proposals made by it prove not to be acceptable to the other so long as their proposals have received adequate consideration.

The offer of arbitration is the subject of the letter to our council published by Dr. Hugh Woods and received the fullest consideration by the executive officers and finally by the council. From this letter we inferred that the council of the Medical Protection Society was prepared to leave everything to what may rightly be called the "chances" of arbitration; that there was no one point considered by them to be of such importance to the interests of their society that they wished to reserve it from these chances. Our council held a different view and was not prepared to risk every point which was considered crucial and of the greatest importance to the welfare of our society to such uncertain chances, and decided that they were unable to accept the proposal.

If you will be so good as to publish this statement I think it may help to allay the irritation which seems to be inseparably attached to collective negotiations on this subject and serve to convince the members of both societies that the wisest course under the circumstances is for each to develop to the best of its power its resources for the benefit of its members, and for each to continue in friendly rivalry, endeavouring to excel the other in its efforts for the good of the profession, until at some future time perhaps the only practicable solution, as it appears to me, takes placenamely, that one society, acting on the belief that it was to the interest of the protession to do so, winds up its affairs and merges into the other. Fach society is too independent and successful at the present time for this to be likely to occur; in the meantime let us regard each other collectively as we do individually, with the consideration and good feeling which we deserve for the valuable work we are doing willingly and gratuitously for our professional brethren and whioh is known as medical defence.

May I take this opportunity of expressing the high appreciation which is felt by all for the practical interest which you take in the matter and the generous offer you made in connexion with it?

I am, Sirs, yours faithfully,

Dec. 18th, 1899.

WAlter S. A. Griffith, President of the Medical Defence Union.

\section{DR. LOMBE ATTHILL AND THE APOTHE- CARIES' HALL OF DUBLIN. \\ To the Editors of THW LANCET.}

SIRS,-In THE LANCET of Dec. 16th you publish a vote of censure passed on me by the governor and directors of the Apothecaries' Hall of Dublin in which they denounce the course $I$ adopted in expressing the views held by the President and Fellows of the Royal College of Physicians of Ireland at the recent meeting of the General Medical Council as "most unprofessional, totally uncalled for, and highly discreditable" to me. I observe, however, that they do not deny the trath of my statements.

As my speech has not been published these gentleman must have derived their information from a one-sided and necessarily imperfect source; indeed, I am of opinion, had they been more perfectly informed as to the merits of the case, that the resolution would have been modified. Did the matter concern myself alone I should not have thought of noticing it, but as I expressed the views of the President and Fellows of the Royal College of Physicians of Ireland, whom I represent on the Council, it is but right that the facts of the case should have the same publicity as was given to the resolution of the Apothecaries' Hall. Personally I was, after the passing of the Act of 1888, in favour of admitting examiners appointed by the Apothecaries' Hall of Dablin to take part in the conjoint examination about to be conducted by the Royal College of Physicians and Royal College of Surgeons of Ireland and I moved a resolution to that effect, and it was not till revelations were made in the General Medical Council in 1895, which ended in the examinations conducted by the Apothecaries' Hall of Dublin and the College of Surgeons jointly being reported to the Privy Council and being discontinued, that I saw reason to alter my opinion.

At the recent meeting of the General Medical Council Mr. Brown moved two resolutions, one approving the establishment of an examining board for kngland to include the Apothecaries' Hall of London; the other, that steps be taken to try to establish a similar board for Ireland, to include the two Royal Colleges and the Apothecaries' Hall of Dublin, and he called on me to give the reasons why the College of Physicians continued to refuse to agree to such, and I felt bound to do so. Capital having been made of the fact that the first of Mr. Brown's resolutions had been carried by a majority, though small, I in my statement in the first instance pointed out that there was no analogy between the two bodies referred to, and that $(a)$ the Apothecaries' Society of London was constituted a corporate body by the name of the "Society of Apothecaries of London." The Dublin body were created by the Act 40 , Geo. III., C. 35, to raise a fund to erect a hall for the purpose of preparing "medicines of the purest quality under the inspection of persons skilled in the art and mystery of an apotbecary" and to protect the public from the "frauds and abuses practised by ignorant and unskilful persons pretending to the art of an apothecary to the injury of the fair trader, the disappointment of the physician, and hazard of life." (b) The London Society had powers to appoint a court of examiners to "ascertain the skill and abilities of such persons in the science and practice of medicine and their fitness to practice as an apothecary." The powers conferred on the Dublin Hall are that " no person shall open 
shop or act in the art and mystery of an apothecary in Ireland until he shall have been examined as to his qualifcation and knowledge of the business" by "the governor, deputy governor, and directors of the Apothecaries' Hall of Dublin." The Dublin Hall had no powers given to appoint any examiners otber than those named above or to examine in medicine as the London Society has. (c) The London Society has power to inspect apothecaries' shops and inflict fines; the Dublin Hall has not that responsible duty entrusted to it; that was imposed on the College of Physicians of Ireland and was regularly performed by it up to the date of the passing of the Act consituting the Pharmaceutical Society of Ireland. (d) A candidate rejected by the Dublin Hall can appeal to the College of Physicians; this right has been repeatedly exercised. No such supervision is conferred on the Royal College of Physicians of London. With respect to the London Hall, the President and Fellows of my College held, when the subject of admitting the Dublin Hall to participate with College of Surgeons in forming with them a conjoint examining board was under discussion, that the fact of the Hall being subordinated to the College in these and other matters by the provisions of the Apothecaries' Act (Ireland), specially with respect to the right of appeal in the case of a rejected candidate, rendered it inexpedient to agree to such a combination.

Further, there was a legal difficulty as to the fee for the joint Licences; the Apothecaries' Hall of Dublin is bound by the Act to charge "the sum of ten shillings and no more" for its certificate. That sum would not pay the cost of the examination, but if the Hall charged a larger sum the College would be conniving at an illegal act; further, candirlates would have objected to pay such for a Licence very few desired to hold and the great majority refused to go in for. There was, further, a legal difficulty with regard to the provisions of the Apothecaries' Act. By it the governor and directors of the Hall are bound to enforce an apprenticeship of seven years on all candidates for their Licence. As a matter of fact, they have allowed this to fall into abeyance, but the College of Physicians could not be a party to any evasion of the law. These were the reasons which in 1889 mainly influenced the President and Fellows to decide not to agree to admit the Apothecaries' Hall of Dublin to take part in the scheme for the establishment of an examining board under the provision of the Act of 1888, and all these still exist. Further, I stated that since 1889 matters of public notoriety had occurred with reference to the Apothecaries' Hall which had confirmed the College as to the correctness of its decision. The Apothecaries' Hall of Dublin was established by the Legislature solely with the view of protecting the public from the injury which follows the use of impure or adulterated drugs, and it was the duty of the board of directors to prevent the sale of such in Ireland; but instead of doing so, and while admitting that " drug contracting in Ireland to be in about as: corrupt a state as possible and a matter of disgrace to public bodies," it is openly stated by the Medical Press and Circular-and the statement has not been contradicted-that "the Apothecaries' Hall of Dublin has descencled from its high estate to join in the discreditable scramble for union contracts, adopting the same tactics as the rest of the commercial crowd who fatten at the expense of the ratepayers and the sick poor," and after comparing the gross price of 74 articles which would be supplied by an English firm with the price offered by the Apothecaries' Hall of Dublin it adds: "We are obliged to conclude that the 'Hall' has entered the lists as one of the ruck of drug traders who deal with boards of guardians and is willing to adopt their methods. We do not know that we could say anything worse" (vide Supplement Medical Press and Cireular, Sept. 23rd, 1896).

I read extracts from this article to the Council and it was having these in my mind that I concluded by saying that, in my opinion, the Apothecaries' Hall of Dublin was not a body any of the medical corporations having due regard to its reputation ought to combine. That opinion I cannot alter. I leave it to your readers to decide if I should do so and whether my conduct in stating the views of the College I represent when called on to show cause why we refuse to join with them is " most unprofessional, totally uncalled for, and highly discreditable" to me. I am willing to abide by the verdict of my profession.

I am, Sirs, yours faithfully,

\section{SUBCUTANEOUS INJECTIONS OF MORPHINE} FOR WOUNDED MEN.

\section{To the Editors of THE LANCET.}

SIRS, - The utility of morpbine injections in saving suffering during the removal of wounded men seems so obvious that you may think it unnecessary to insert this letter, but some years ago I was a good deal struck by the account given me by $m y$ friend Professor Bit $z$ of Bonn of the use which he made of subcutaneous injections in the FrancoGerman war while engaged in superintending the removal of the wourded. He went about armed with a bottle of morphine solntion and a bypodermic syringe, and before a man was removed he gave him a subcutaneous injection which put the man to sleep, prevented any pain during removal, and lessened shock, so that the patient was in a better condition for operation when be arrived at the hospital in the rear. It sometimes happens that measures of treatment which are perfectly obvious may occasionally, uncler the stress of circumstances, slip from an operator's mind, and I think it worth while to trouble you with this letter on the bare possibility of preventing pain from such cause. I am, Sirs, yours faithfully,

Stratford place, W., Dec. 14th, $1899 . \quad$ T. LAUDER BrUNToN.

\section{A QUESTION OF LUNACY FEES.}

To the Editors of THE LANCET.

SiRS,-I have recently had a difference with the Chertsey guardians in reference to the payment of fees for the certifying of lunatics and I should be very glad of your opinion in the matter. I was asked some while ago by the relieving officer if $I$ would attend at the union on a certain date in crder to certify seven cases of lunacy. I am not a parish doctor and was called in in a private capacity. I certified the cases in due course and was afterwards informed that the guardians had decided to pay me half a guinea for each case. This I would not accept as I should never dream of certifying for less than a guinea and that is little enough for such responsibility. They, however, refuse to pay more because they were all certified at the same time and tell me I have my remedy. I may say that I entered into no contract beforehand and the question of fee was never mentioned. I should be most glad of your opinion in the matter as I think it is of great importance to the profession.

I am, Sirs, yours faithfully,

J. L. ALLEN HOPE, M.R.C.S.Eng., L.R.C.P. Lond.

** Our correspondent should approach the Justice who was concerned in the certifying of these cases. The amount of fee payable to a medical man in these circumstances is left by statute entirely to the discretion of the Justice, and the guardians have no option but to pay whatever sum he makes the order for. The fee usually ordered by the Justice varies from half-a-guinea to two guineas. It is only fixed as low as half-a-guinea where the certifying medical man is the medical officer of the workhouse and he sees the case in the course of his daily visits and as part of his daily routine at the workhouse. When an outside medical practitioner is employed who has to make a special visit, sometimes more than one visit, the fee payable is always one or two guineas. The argument advanced of "reduction on taking a quantity" hardly applies in such circumstances because the responsibility in each individual instance is the same however many alleged lunatics there may be. The sum of two guineas is frequently paid to an outside practitioner when there is only one case ; and however many cases there are it shculd not be less than one guinea each.-ED. L.

\section{ACUTE INEECTIVE ARTHRITIS AND CELLULITIS.}

To the Editors of THE LANCET.

SIRS, - I wish to draw attention again to the erroneous treatment generally practised in "acute rheumatism," persistence in which I can only attribute to the natural disinclination medical men have in renouncing the dogmas of their clinical masters and book authorities. A most interesting case was published by Dr. D. B. Lees and Dr. F. J. Poynton 